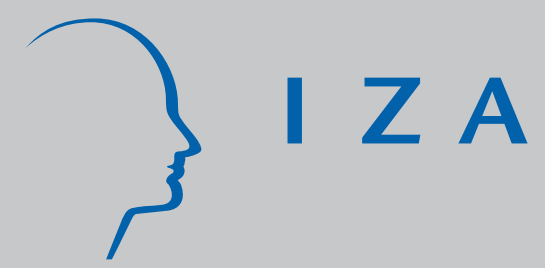

IZA DP No. 6160

A Challenge for the G20:

Globally Stipulated Debt Brakes and

Transnational Independent Fiscal Supervisory Councils

Mathias Dolls

Andreas Peichl

Klaus F. Zimmermann

November 2011 


\title{
A Challenge for the G20: Globally Stipulated Debt Brakes and Transnational Independent Fiscal Supervisory Councils
}

\author{
Mathias Dolls \\ $I Z A$ \\ Andreas Peichl \\ $I Z A$ \\ Klaus F. Zimmermann \\ IZA and Bonn University \\ Discussion Paper No. 6160 \\ November 2011 \\ IZA \\ P.O. Box 7240 \\ 53072 Bonn \\ Germany \\ Phone: +49-228-3894-0 \\ Fax: +49-228-3894-180 \\ E-mail: iza@iza.org
}

\begin{abstract}
Any opinions expressed here are those of the author(s) and not those of IZA. Research published in this series may include views on policy, but the institute itself takes no institutional policy positions.

The Institute for the Study of Labor (IZA) in Bonn is a local and virtual international research center and a place of communication between science, politics and business. IZA is an independent nonprofit organization supported by Deutsche Post Foundation. The center is associated with the University of Bonn and offers a stimulating research environment through its international network, workshops and conferences, data service, project support, research visits and doctoral program. IZA engages in (i) original and internationally competitive research in all fields of labor economics, (ii) development of policy concepts, and (iii) dissemination of research results and concepts to the interested public.
\end{abstract}

IZA Discussion Papers often represent preliminary work and are circulated to encourage discussion. Citation of such a paper should account for its provisional character. A revised version may be available directly from the author. 
IZA Discussion Paper No. 6160

November 2011

\section{ABSTRACT}

\section{A Challenge for the G20: Globally Stipulated Debt Brakes and Transnational Independent Fiscal Supervisory Councils}

Debt-to-GDP ratios have grown to unprecedented levels in many industrialized economies. This requires disciplined consolidation efforts which are, however, supposed to come now at the wrong time with the economic recovery being fragile. Against this background, we call for a global debt brake following the German example and discuss the political progress achieved at the most recent Euro and G20 summits. The agreement on the debt brake should be binding and hence be fixed in national constitutions and monitored by independent transnational fiscal councils. The fiscal councils could be located at the ESM and the IMF and should conduct a regular evaluation of national budget plans. In an economic and political environment which is characterized by large uncertainties concerning economic prospects and the fear of a potential spreading of the sovereign debt crisis, a global debt brake in combination with an independent transnational supervisory council would send a credible signal that a reduction of sovereign debt to sustainable levels is not further delayed into the future. The new fiscal policy framework thus leaves enough room for discretionary fiscal policy and the workings of automatic stabilizers in an economic downturn.

JEL Classification: $\mathrm{H} 1, \mathrm{H} 3, \mathrm{H} 6$

Keywords: debt brake, fiscal council, G20

Corresponding author:

Klaus F. Zimmermann

IZA

P.O. Box 7240

53072 Bonn

Germany

E-mail: zimmermann@iza.org 


\section{Introduction}

The current Eurozone crisis is a sovereign debt crisis which has its roots in a failure of the Maastricht Treaty and the exorbitant anticyclical measures passed in the Great Recession. ${ }^{1}$ It started in Greece whose fiscal policy did not show the necessary quality neither before nor after admission to the Eurozone and has spread also to other countries in Europe (Ireland, Portugal, Spain, Italy). Political leaders have recognized the necessity of institutional reform in the Eurozone. The European Stability Mechanism (ESM) is designed to act as a permanent insurance mechanism from 2013 onwards and the Maastricht Treaty shall become more restrictive with respect to fiscal policy supervision. Further, after their meetings in August and October, Angela Merkel and Nicolas Sarkozy have called for a debt brake for all Eurozone countries and a recapitalization for European banks. Only recently, the United States reached a consensus to increase the debt ceiling again, but the Congress' super committee which should negotiate $\$ 1.2$ trillion in budget cuts as required by the debt deal failed to reach an agreement due to the current political divide between Democrats and Republicans.. This failure implies that efforts to reduce the deficit will be delayed until the next Presidential election in 2012. On their summit in late October, political leaders of the Eurozone countries mainly focused on emergency measures such as leveraging resources of the European Financial Stability Facility (EFSF) and a discount on Greek public debt held by private investors, but also acknowledged the importance of national debt brakes and proposed a strengthening of the European Commission with regard to economic and fiscal surveillance of euro area countries. At the G20 summit, fiscal consolidation targets passed at previous summits in Toronto and Seoul were confirmed, but no further agreements aimed at a structural solution of the crisis were reached.

Despite of the emergency measures to combat the sovereign debt crisis, credit ratings for US and Italian government bonds are downgraded by Standard \& Poor's and Moody's. The uncertain political environment which casts sustained consolidation efforts into doubt is a main reason for the downgrading. Fitch downgraded its ratings of Italy and

\footnotetext{
1 This article is a revised version of IZA Policy Paper No. 33 "A Challenge for the G20: Globally Stipulated Debt Brakes and Transnational Independent Fiscal Supervisory Councils" (Dolls et al., 2011) which called on political leaders of the G20 to put a global debt brake complemented by transnational supervisory councils on the agenda of the G20 meeting in Cannes in early November 2011. We review the political progress achieved at the most recent Euro and G20 summits with regard to our initial claims. The media coverage of our call for action is summarized under http://www.iza.org/en/webcontent/news?item=358. See in particular the more than 12 op-eds in international newspapers, including Zimmermann (2011b, 2011c, 2011d).
} 
Spain; Moody's did the same for Belgium and 21 European banks. A downgrading of further G20 countries is likely to follow. For example, Fitch announced that it might reduce the ratings of China and Japan. Standard \& Poor's made clear that even ratings for German and French government bonds might be reconsidered in the course of the Eurozone crisis if their debt guarantees further grow.

Against this backdrop, the transatlantic political strategy to defer necessary reforms into the future must come to an end. The time to act is now and it is the $\mathrm{G} 20$ that has to take the lead. Besides the emergency measures taken in the Eurozone and the debt deal in the US which only provide short-term relief, structural reforms to overcome the sovereign debt crisis are desperately needed. The G20 is the right place for the negotiation of global reform measures. The member countries represent about $90 \%$ of global GDP, $80 \%$ of international trade and about two thirds of the global population. The G20 does not only include representatives of countries with the highest debt levels (EU, US, Japan), but also the BRIC countries and large developing economies whose impressing growth performance is particularly threatened by the sovereign debt crisis. BRIC countries, in particular China, have an important role for the stabilization of the world economy. The BRIC group and other large developing countries such as Turkey, Mexico or Indonesia should also vouch for world regions which are particularly under-developed and not part of the G20: If there is no solution to the sovereign debt crisis, rich countries will provide less foreign aid in the medium term.

Part of the rising debt levels in many advanced economies results from government interventions to stabilize the financial sector and large fiscal stimulus packages during the Great Recession. But by no means is the Great Recession the only cause of the current sovereign debt crisis which is one of the most urgent challenges at the beginning of the 21st century. Debt-to-GDP ratios have been unsustainable in some Eurozone countries and Japan even before fiscal stimulus packages acted as an accelerator of public debt. High levels of sovereign debt do not only threaten economic recovery around the world (see e.g. Reinhart and Rogoff (2010) who find that real GDP growth is negatively affected by debt/GDP ratios if the latter are above 90 percent) but also impose large burdens for future generations. In addition, the debt levels are expected to grow further over the next decades due to demographic trends and population ageing (Eichengreen et al., 2011). 
There is the widespread view that at present the need for fiscal consolidation comes at the wrong time. Fiscal austerity usually leads to slower growth and might increase unemployment (Ball et al., 2011). The weak economy and fear of a double dip recession have prompted Barack Obama's administration to announce a new stimulus program, the American Jobs Act, and to call for similar programs in other countries. However, the opposing argument is based on the view that increased uncertainty among consumers and investors - with regard to economic prospects and the response of economic policy to overcome the sovereign debt crisis - might negatively impact the economy (see e.g. Bloom, 2009, and Baker et al., 2011). Following this argument, consolidation plans which are perceived by economic actors as credible commitments are an important step towards higher confidence and increased economic activity. As most governments around the world are already constrained by high levels of existing debt and are still running deficits, it is indispensable that policy makers take action to reduce the uncertainty about public finances and thus ensure their long-term sustainability.

Therefore, we call for a global debt brake which stipulates a long-term consolidation path. In particular the advanced economies which have high levels of public debt need to fix a debt brake in their national constitutions immediately. But in the long run, it is recommendable that all G20 countries implement a debt brake in order to stop the increase of global sovereign debt - including those developing countries with rather low levels of public debt today. The debt brake should follow the German or Swiss example, augmented by independent, transnational supervisory councils that allow for "constrained discretion" (Fatas and Mihov, 2010). The task of the fiscal councils will be to evaluate national budget plans and to monitor compliance with the rules of the debt brake in order to enact a global early warning system with the aim to avoid sovereign debt crises in the future. The fiscal councils could be located at the ESM and the IMF. Thus, the institutional framework for a global early warning system which consisted so far of the Financial Stability Board, the successor of the Financial Stability Forum founded in 1999 with the task to supervise the financial markets, would be consistently expanded with regard to a global supervision of sovereign debt. 


\section{The problem of rising debt levels in industrialized countries}

The pattern of a sovereign debt crisis following a banking crisis is recurring in economic history (Reinhart and Rogoff, 2011). Economic crises which have its origin in the financial sector tend to have particular strong effects on output and employment. The financial crisis which started in 2008 turned later into the Great Recession. In particular the industrialized countries were confronted with large reductions in GDP (see Figure 1). The policy response was to stabilize the financial sector and to enact large fiscal programs which should - in addition to the workings of automatic stabilizers (cf. Dolls et al., 2010) - stimulate the economy. These measures led to large budget deficits (Figure 2a) and rising debt levels (Figure 2b). Within the G20 there is considerable heterogeneity. High levels of public debt can be observed in particular for the advanced economies (Japan, Italy, US), whereas levels are still rather low in some of the fast-growing emerging economies (Figure 3).

9 out of 19 countries of the G20 will have debt levels above 60 percent of GDP at the end of 2011. This is also true for the EU as a whole. A similar picture emerges for budget deficits. At the end of this year, 10 countries belonging to the $\mathrm{G} 20$ will have a deficit above 3 percent. Projections of the IMF show that the debt-to-GDP ratios will only marginally decline until 2016, if at all. Among the G20-countries with the highest levels of public debt, no country will reduce its debt-to-GDP ratio below the pre-crisis level of 2007 until 2016 (Figure 4). Hence, fiscal policy conditions will deviate from what is stipulated by the Maastricht Treaty at least in the medium term, but probably also in the long-term.

IMF projections (Figure 2a,b) show that $\mathrm{G} 20$ countries are on a consolidation path in terms of deficit reduction but this will not be sufficient to reduce debt-to-GDP ratios since in times of low economic growth surpluses and not only reduced deficits are necessary for a substantial debt reduction. However, the current situation is marked by a large degree of uncertainty about the economic recovery which is crucial for a successful consolidation. This uncertainty is exacerbated by the ongoing Eurozone crisis and unsustainable debt levels in many other G20 countries such as Japan or the United States. These fiscal constraints become more and more binding and impede further stimulus programs: the sovereign debt crisis cannot be overcome by running into even more debt. 


\section{G20 summits in Toronto, Seoul and Cannes and the most recent Euro summit: commitments and current state of implementation}

The sovereign debt crisis was already on the agenda of the two G20 summits in 2010 which took place in Toronto and Seoul. G20 leaders agreed on concrete consolidation efforts, in particular for the advanced economies. According to the Toronto commitment, budget deficits are to be at least halved by 2013 and the government debt-to-GDP ratios have to be stabilized or even reduced by 2016 (G20, 2010a). Concrete measures for each country were agreed upon in the Seoul Action Plan (G20, 2010b). At the most recent summit in Cannes in November 2011, political leaders of the G20 confirmed these resolutions but did not go beyond. The Cannes Action Plan of Growth and Jobs $(G 20,2011)$ states that fiscal rules are in place in some countries to reinforce consolidation plans. But there was no initiative at the Cannes summit for a structural solution to the sovereign debt crisis which makes the consolidation process binding - neither a debt brake for all G20 countries nor the introduction of independent fiscal supervisory councils were on the agenda. Hence, we conclude that the G20 summit in Cannes did not meet the expectations expressed in our pre-summit call (Dolls et al., 2011).

The Euro summit in late October 2011 mainly focused on emergency measures such as a leveraging of the EFSF resources and a discount on Greek public debt held by private investors. Besides these measures which do not tackle the structural causes of the sovereign debt crisis - namely excessive public debt accompanied by non-competitive economies at the periphery of the Eurozone - some progress has been achieved with respect to a more stringent governance of the euro area. However, in the Euro Summit Statement (EU, 2011), the importance of national fiscal rules which translate the Stability and Growth Pact into national legislation is stressed. Furthermore, the role of the European Commission, in particular the responsibilities of the Commissioner for Economic and Financial Affairs, in the monitoring process of Eurozone members which are in excessive deficit procedure is strengthened. While these proposals are important steps towards a stabilization of the Eurozone, they are still insufficient for a long-term solution since they do not guarantee fiscal surveillance in the Eurozone which is politically independent. As long as it is a deficit country and not an independent body which monitors its peers, compliance with fiscal rules is unlikely as experience with the Stability and Growth Pact has shown. 


\section{What needs to be done}

The resolutions of the Euro summit in October 2011 are only a first step towards national debt brakes in the euro area which needs to be transferred into national law by each member state of the Eurozone. Some Eurozone countries have already implemented a debt brake (Germany, Spain) or have committed to do so in the future (Austria, France, Italy). With regard to fiscal supervision, the Euro Summit resolution does not contain a proposal which stipulates an independent supervisory framework. Here, a further development towards transnational and independent fiscal supervisory councils is needed. In addition, the Eurozone needs clear exit rules (see Fahrholz and Wójcik, 2011). Furthermore, in order to reduce the systemic risk of a financial crash due to the bankruptcy of a country and the following negative externalities, the equity requirements of banks need to be strengthened substantially.

The G20 summit in Cannes did not show progress with regard to an agreement on stronger fiscal consolidation efforts relative to the G20 summits in Toronto and Seoul in 2010. Therefore, our claim that G20 countries need a credible commitment to reduce government debt, not least to ease international financial markets, is still valid (Dolls et al., 2011). The inability of governments to maintain fiscal discipline is not new and empirical evidence shows that constrained governments tend to deliver better fiscal policy (Fatás and Mihov 2003 and 2006). Rotte and Zimmermann (1998) show that by committing itself to the rules of the Maastricht Treaty the European Union made early progress in terms of fiscal stability. They argue that at that time the Maastricht Treaty served as a political-economic concept which used the popularity of the European idea to successfully enforce fiscal discipline on a national level, even at the cost of rising unemployment and slowing growth.

The successful fiscal austerity at that time was, however, based on the high popularity of the European integration, which more and more disappears nowadays and is replaced by a phase of disillusion. For this reason, today it is sensible and necessary to establish the right mix of instruments on different political levels with a debt brake fixed into national constitutions and monitored by independent transnational supervisory councils.

Given that the sovereign debt crisis is not restricted to the Eurozone, but constitutes a global challenge for the majority of advanced economies around the world, and given the large degree of international interdependence, the G20 is the right place for this kind of international policy coordination. Importantly, the global debt brake serves also the interests 
of the BRIC countries and other fast-growing economies. Their economies would be substantially affected by a spreading of the sovereign debt crisis and a resulting increasingly cloudy economic outlook. Moreover, it is their self-interest which should restrain them from accumulating debt levels as high as in the advanced economies. For these reasons, the agreement on a global debt brake should be part of a further development of a grand bargain for the G20 (Goldstein, 2009).

\section{Benefits of a globally implemented debt brake fixed into national constitutions}

Implementing debt brakes in national constitutions in all G20 countries which are internationally enforced leads to several important benefits for future fiscal stability. First, the necessary consolidation plans gain credibility and accountability. This contributes to reduced sovereign risk premia (see e.g. Hallerberg and Wolff, 2008, for the European Monetary Union). Second, liquidity crises of countries which are not insolvent could be avoided (see Fuest, 2011, for a short discussion of multiple equilibria in financial markets). In addition, by imposing that surpluses have to be generated in good times, pro-cyclical discretionary policy which is itself a source of macroeconomic volatility becomes less likely (see e.g. Fatás and Mihov, 2003, Holm-Hadulla et al., 2011). At the same time, there should be enough room for automatic stabilizers and some discretionary action in economic downturns. Finally, such a policy ensures that the provision of debt-financed stimulus measures is only temporary.

\section{Which form of debt brake?}

Different forms of fiscal rules exist and some of them used in the past have proven to be ineffective. For example, golden rules which limit public net borrowing to the amount of gross/net public investment (the former rule in Germany) or simple deficit rules such as the one of the Maastricht Treaty did not avoid excessive accumulation of public debt. A main problem with these kinds of rules is their asymmetry over the business cycle, i.e. they do not require governments to create budget surpluses in good times. At the other extreme, stringent budget requirements or spending limits (e.g. as they are in place in some of the US states) which require a balanced budget in each period should not be applied at the federal level. They have the drawback that fiscal policy can become procyclical and hence might 
exacerbate economic downturns (see e.g. Fatás and Mihov, 2010). In the US, the federal government can counteract the recessionary impact of state fiscal policy.

More promising are fiscal rules such as the Swiss or German debt brake (see e.g. Feld, 2010, for an analysis of the German debt brake and Bodmer, 2006, for the Swiss case). A key characteristic of these rules is the aim to achieve a balanced budget in the course of a business cycle. This can be achieved by tying spending to structural revenue or by restricting the structural budget deficit. Pro-cyclicality of fiscal policy shall thus be avoided. For the sake of credibility, the debt brake should have constitutional standing. However, the enforcement of the rules has to be assured.

\section{Major problem: Enforcement}

A major problem with the EMU stability and growth pact was the enforcement of the rules. While the general idea was good in theory (balanced budget, maximum deficit of $3 \%$ of GDP in bad times allowed in order to keep debt levels below 60\% of GDP), in practice, however, the $3 \%$ deficit limit was interpreted as the rule for good times and not the exemption for bad times. As soon as France and Germany violated this without any consequences, the Stability and Growth Pact was ultimately damaged.

In order to illustrate the potential path how public debt would have developed throughout the last decade if governments had complied with the Maastricht Treaty, we calculate hypothetical debt/GDP ratios for the pre-crisis year 2007 and for 2011 for selected G20 and EU member countries. For this purpose, we define compliance with the Maastricht Treaty in the sense that budgets have to be balanced (or even show a surplus if this actually occurred) in years with positive real GDP growth while deficits of $3 \%$ of GDP are allowed when real GDP growth is negative. For the crisis years 2008-2011, we consider two scenarios. Scenario a) simply extrapolates the calculations of the period 2001-2007, i.e. compliance with the Maastricht Treaty is assumed, whereas scenario b) is based on observed budget balances. Scenario $b$ ) is justified on the grounds that higher deficits due to extraordinary circumstances such as the Great Recession should be in accordance with any meaningful debt brake.

An important finding of this simulation exercise is that Eurozone countries such as France and Germany, but also Canada and the United States, would have had debt-to-GDP ratios well below $60 \%$ in 2007, had they complied with the Maastricht rules in the 2000s. In 
reality these countries already had debt / GDP ratios higher than $60 \%$ even before the start of the Great Recession. High debt levels in 2007-2008 might have limited some governments to appropriately react to the economic crisis. For example, in a recent paper Aizenman and Jinjarak (2011) find that the size of the fiscal stimulus programs passed in 2009-2010 is negatively related with fiscal space before the start of the Great Recession.

A comparison of actual debt / GDP ratios in 2011 with those resulting from our hypothetical calculations shows that public finances would be much healthier today if countries had complied with a budget rule such as the one of the Stability and Growth Pact. Countries such as Greece and Portugal which have been covered by stabilization mechanisms from the IMF, the ECB and the European Commission or Italy which faced an increase in its sovereign risk premia in recent months due to insufficient consolidation efforts would probably have fewer problems today to refinance their government debt. Further, countries would have more fiscal room today to act against a possible double dip recession.

These simulations clearly have to be treated with caution. They are based on the strong assumption that the economy would have developed as it actually did if governments had complied with the Maastricht Treaty. In some cases this is highly implausible. For example, in the Great Recession the Irish government was confronted with the collapse of its banking system which made interventions inescapable. Nevertheless, these hypothetical calculations demonstrate which path government debt would have taken if enforcement had worked and that a fiscal rule which is reasonable from an economic point of view turns out to be completely ineffective if governments do not comply with it.

\section{Independent fiscal policy councils}

In order to ensure enforcement of the debt brake's rules - which is not guaranteed alone by its constitutional standing - its compliance should be monitored and regularly evaluated by independent fiscal policy councils (see also Calmfors, Wren-Lewis, 2011). In the context of the debate to reform the Maastricht Treaty at the beginning of the last decade, it has been suggested to establish such a supervisory council as an independent European institution serving as a complement to the European Central Bank (Zimmermann, 2002a, 2002b, 2003, 2004; Brück et al., 2003) in order to limit national differences and to make the rules of the Maastricht Treaty politically enforceable. Proposals for national councils can be found in 
Wyplosz (2005), von Hagen and Harden (1995), Fatás, Siebert, Hughes-Hallet, Strauch and von Hagen (2003) and, most recently, in Schuknecht et al., 2011. Some countries have already started moving in this direction and made first experiences with national councils (e.g. Canada, Hungary, Slovenia, Sweden and the UK). The fiscal councils could be located at the European level at the ESM and internationally at the IMF and operate as a budget office (see Zimmermann, 2011a; Schuknecht et al., 2011). Sanctions in case of non-compliance with the debt brake would depend on the specific setting, but could be imposed in the form of fines or other restrictions.

Independent fiscal policy councils are a good complement to strict budgetary rules for various reasons (see e.g. Fatás and Mihov, 2010). They can monitor and enforce such rules and prevent governments from manipulating numbers. In addition, such a council can give advice when it might be reasonable to depart from the fiscal rules, e.g. in times of extraordinary recessions when the budgetary rule might only be a poor approximation to optimal policy.

\section{Reducing deficits}

In order to reduce deficits and debts, no magic formula exists. The best way to reduce government debt is through growth (increasing the denominator). Growth potentials can be increased through various reforms of labor and product markets. In addition, in countries with high unemployment, more active labor market programs as well as programs to increase consumer confidence can be helpful. However, growth alone will not be enough to reduce debt to sustainable levels in many countries.

Therefore, in addition spending cuts and tax increases seem necessary. However, these measures might lead to slower growth and negative employment effects (Ball et al., 2011). Therefore, the right mix of policies has to be found. Of course, there is no "one size fits all"-formula for every country and the optimal policy mix depends on the specific circumstances. In general, countries with rather high spending-to-GDP ratios could try to reduce expenditures more whereas countries with low tax-to-GDP ratios could work more with tax increases.

The effects of such austerity measures on growth depend on various factors. In general, spending cuts are found to be less recessionary than tax increases (Alesina and Ardagna, 2010). For spending cuts, on the one hand, in every country a list of wasteful 
government spending exists which should be eliminated. In addition, certain expenditures of government consumption can actually harm growth and cutting those would reduce the deficit and increase growth at the same time (see Afonso et al., 2005, and Afonso, 2006).

When increasing taxation, it is important to look at the tax mix. Reducing corporate taxation and increasing indirect taxation increases investment and growth (see e.g. Gordon and Lee, 2005, Martinez-Vazquez et al., 2009). In addition to increasing indirect taxes, property taxes should be increased as well (Arnold et al. 2011). Furthermore, reducing the tax burden on lower incomes is more likely to increase employment and to have positive growth effects than doing this at the top (Arnold et al. 2011). Therefore, increasing the taxes on the rich, as popularly requested even by themselves (Buffett, 2011), is another option to increase tax revenue. Furthermore, simulation studies show that the top marginal tax rate in optimal tax models is usually very high (above 60\%) even when taking into account behavioral responses (Aaberge and Colombino, 2010, and Bach et al. 2011). In addition, estate and inheritance taxes could be introduced or extended. Another policy instrument which only the G20 can realistically propose is a global tax on financial transactions (Matheson, 2011). In addition to raising revenue, this instrument would also increase the price for aggressive speculation on financial markets and could help to calm them down.

\section{Conclusions}

The financial and economic crisis is not over yet, but followed by a sovereign debt crisis. The time for governments to commit to credible long-term consolidation is now, and this commitment is needed even in the short-term for the sake of increased confidence among consumers and investors and lower sovereign risk premia. The debt crisis calls for a reduction of government debt to sustainable levels. Therefore, G20 countries should commit to enact a global debt brake following the Swiss or German example. At the same time, it is recommendable to establish transnational independent fiscal supervisory councils which as a complement to monetary policy - take over the regulation of fiscal policy. They could be located at the ESM and the IMF. In this paper, we have reviewed the progress made at the most recent Euro and G20 summits in late October / early November 2011, discussed the benefits of such a policy-mix and have shown how a well-designed debt brake, fixed in national constitutions and augmented by independent fiscal councils, could be implemented on a global level. 


\section{References}

Aaberge, R. \& Colombino, U. (2010): Using a Microeconometric Model of Household Labour Supply to Design Optimal Income Taxes, Carlo Alberto Notebooks 157, Collegio Carlo Alberto.

Afonso, A., Ebert, W., Schuknecht, L. \& Thöne, M. (2005): Quality of Public Finances and Growth, ECB Working Paper Series, 438.

Afonso, A. (2006): Expansionary Fiscal Consolidations in Europe, New Evidence, ECB Working Paper Series, 675.

Aizenman, J. \& Jinjarak, Y. (2011): The fiscal stimulus of 2009-2010: Trade openness, fiscal space and exchange rate adjustment, NBER Working Paper 17427.

Alesina, A. \& Ardagna, S. (2010): Large changes in fiscal policy: Taxes versus spending, in J.R. Brown (ed) Tax policy and the economy, NBER and University of Chicago Press.

Arnold, J., Brys, B., Heady, C., Johansson A., Schwellnus, C. \& Vartia, L. (2011): Tax Policy for Economic Recovery and Growth. The Economic Journal, 121(550), p. F59-F80.

Bach, S., Corneo G. \& Steiner, V. (2011): Optimal Top Marginal Tax Rates under Income Splitting for Couples, CEPR Discussion Paper 8435.

Baker, S., Bloom, N. \& Davis, S. (2011): Measuring Economic Policy Uncertainty, Stanford mimeo.

Ball, D., Leigh, D. \& Loungani, P. (2011): Painful Medicine, FINANCE \& DEVELOPMENT, September, Vol. 48, No. 2, p. 20-23.

Bloom, N. (2009): The impact of uncertainty shocks, Econometrica, Vol. 77, No. 3, p. 623-685.

Bodmer, F. (2006): The Swiss debt brake: How it works and what can go wrong, Schweizerische Zeitschrift für Volkswirtschaft und Statistik, Vol. 142 (3), p. 307-330.

Brück, T., Cors, A., Zimmermann, K.F. \& Zwiener, R. (2003): Stability Criteria and Convergence: The Role of the System of National Accounts for Fiscal Policy in Europe, Allgemeines Statistisches Archiv 87, p. $113-131$.

Buffet, W. (2011): Stop coddling the super-rich, New York Times, August 14, 2011.

Calmfors, L. \& Wren-Lewis, S. (2011): What should fiscal councils do?, CESifo Working Paper No. 3382.

Dolls, M., Fuest, C. \& Peichl, A. (2010): Automatic Stabilizers and Economic Crisis: US vs. Europe, NBER Working Paper 16275, forthcoming: Journal of Public Economics.

Dolls, M., Peichl, A. \& Zimmermann, K. F. (2011): A Challenge for the G20: Globally Stipulated Debt Brakes and Transnational Independent Fiscal Supervisory Councils, IZA Policy Paper No. 33.

Eichengreen, B., Feldman, R., Liebman, J., von Hagen, J. \& Wyplosz, C. (2011): Public Debts: Nuts, Bolts and Worries. Centre for Economic Policy Research, September.

EU (2011): Euro Summit Statement, Brussels, 26 October 2011, accessed at: http://www.consilium.europa.eu/uedocs/cms_data/docs/pressdata/en/ec/125644.pdf

Fahrholz, C. \& Wójcik, C. (2011): The Eurozone needs exit rules, CESifo Working Paper, forthcoming.

Fatás, A. \& Mihov, I. (2003): The case for restricting fiscal policy discretion, Quarterly Journal of Economics, November 2003, Vol. 118, No. 4, p. 1419-1447.

Fatás, A. \& Mihov, I. (2006): The macroeconomic effects of fiscal rules in the US states, Journal of Public Economics, Vol. 90, p. 101-117.

Fatás, A. \& Mihov, I. (2010): Fiscal policy at a crossroads: The need for constrained discretion, VoxEU.org, 15 July 2010.

Fatás, A., von Hagen, J., Hallett, A. H., Strauch, R.R. \& Sibert, A. (2003): Stability and growth in Europe: towards a better pact. CEPR Monitoring European Integration, vol. 13.

Feld, L. (2010): Sinnhaftigkeit und Effektivität der deutschen Schuldenbremse, Perspektiven der Wirtschaftspolitik, 11 (3): p. 226-245.

Fuest, C. (2011): Will the reform of the institutional framework restore fiscal stability in the Eurozone?, CESifo Forum, 12 (2): p. 34-39.

Goldstein, M. (2009): A grand bargain for the London G20 summit: Insurance and obeying the rules, VoxEU.org, 19 February 2009.

G20 (2010a): The G20 Toronto Summit Commitments, accessed at: http://www.g20.utoronto.ca/analysis/commitments-10-toronto.html 
G20 (2010b): The G20 Seoul Summit Document, accessed a http://www.g20.utoronto.ca/summits/2010seoul.html

G20 (2011): Cannes Action Plan for Growth and Jobs, accessed at: http://www.g20.utoronto.ca/summits/2011cannes.html

Gordon, R. \& Lee, Y. (2005): Tax structure and economic growth, Journal of Public Economics 89 (56), p. 1027-1043.

Hallerberg, M. \& Wolff, G. (2008): Fiscal institutions, fiscal policy and sovereign risk premia in EMU, Public Choice, 136: p. 379-396.

Holm-Hadulla, F., Hauptmeier, S. \& Rother, P. (2012): The impact of expenditure rules on budgetary discipline over the cycle, Applied Economics, 44:25, p. 3287-3296.

Martinez-Vazquez, J., Vulovic, V. \& Liu, Y. (2009): Direct versus Indirect Taxation: Trends, Theory and Economic Significance, International Studies Program Working Paper Series 0911, at AYSPS, GSU.

Matheson, Th. (2011): Taxing financial transactions: Issues and evidence, IMF Working Paper, March 2011.

Reinhart, C. M. \& Rogoff, K. S. (2010): Growth in a Time of Debt, American Economic Review, 100(2): p. $573-78$.

Reinhart, C. M. \& Rogoff, K. S. (2011): From Financial Crash to Debt Crisis, American Economic Review, 101(5): p. 1676-1706.

Rotte, R. \& Zimmermann, K. F. (1998): Fiscal Restraint and the Political Economy of EMU, Public Choice 94, p. 385-406.

Schuknecht, L., Moutot, P., Rother, P. \& Stark, J. (2011): The Stability and Growth Pact - Crisis and Reform, ECB Occasional Paper Series No 129.

von Hagen, J. \& Harden, I.H. (1995): Budget Processes and Commitments to Fiscal Discipline, European Economic Review, 39 (3-4), p. 771-779.

Wyplosz, C. (2005): Fiscal Policy: Institutions versus Rules, National Institute Economic Review, No. 191, p. $70-84$

Zimmermann, K. F. (2002a): Stabilitätspakt. Die Kriterien der EU sind zu starr, Handelsblatt, 25. April 2002, p. 8.

Zimmermann, K. F. (2002b): Fristverschiebung stärkt den Pakt, Handelsblatt, 2. Oktober 2002, p. 8.

Zimmermann, K. F. (2003): Zur unabdingbaren Reform des Stabilitäts- und Wachstumspaktes, Zeitschrift für Staats- und Europawissenschaft 1, p. 230-239.

Zimmermann, K. F. (2004): Nur Reformen retten den europäischen Stabilitäts- und Wachstumspakt, Zeitschrift für Wirtschaftspolitik 53, p. 72-80.

Zimmermann, K. F. (2011a): Her mit dem EU-Kassenwart, Financial Times Deutschland, 18. August 2011, p. 24.

Zimmermann, K. F. (2011b): Warum wir eine globale Schuldenbremse brauchen, Neue Zürcher Zeitung, 2. November 2011, p. 23.

Zimmermann, K. F. (2011c): How to Deal with West's Debt, China Daily, 4. November 2011, p. 9.

Zimmermann, K. F. (2011d): How to Deal with Western Debt Crisis, The Economic Times (India), 14. November 2011, p. 16. 
Figure 1: Real GDP growth

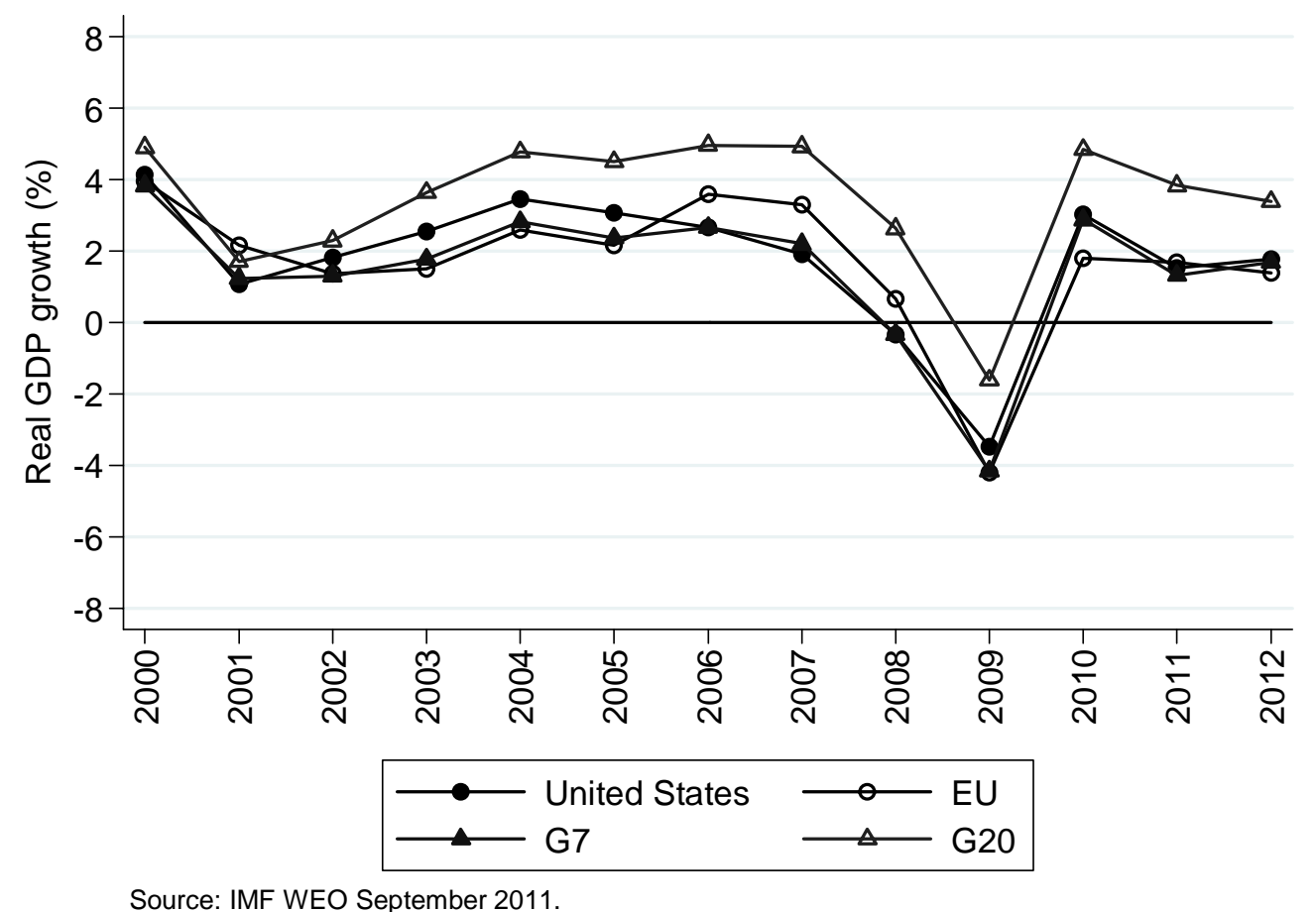

Figure 2a: Development of general budget balance

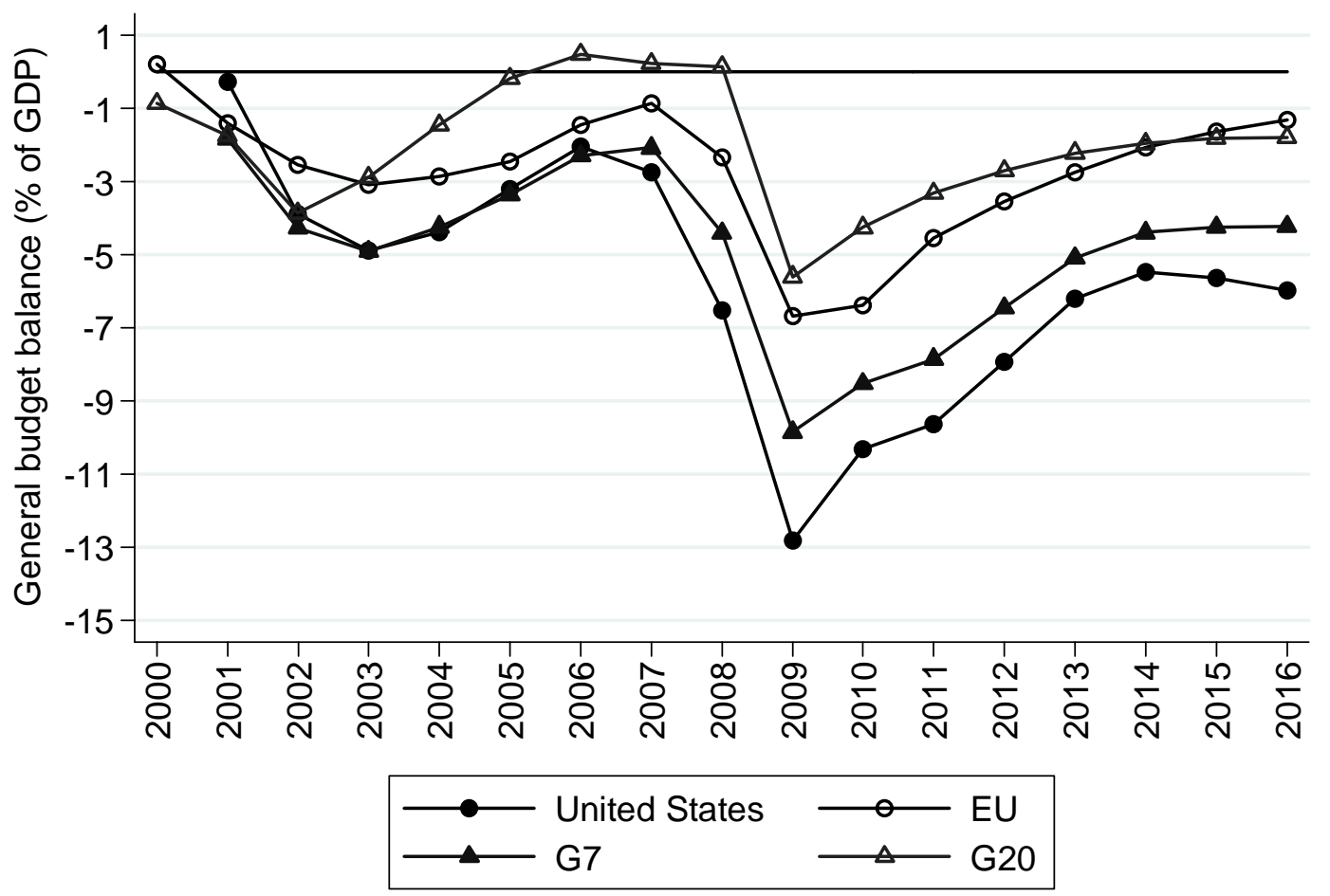

Source: IMF WEO September 2011 
Figure $2 \mathrm{~b}$ : Development of debt-to-GDP ratio

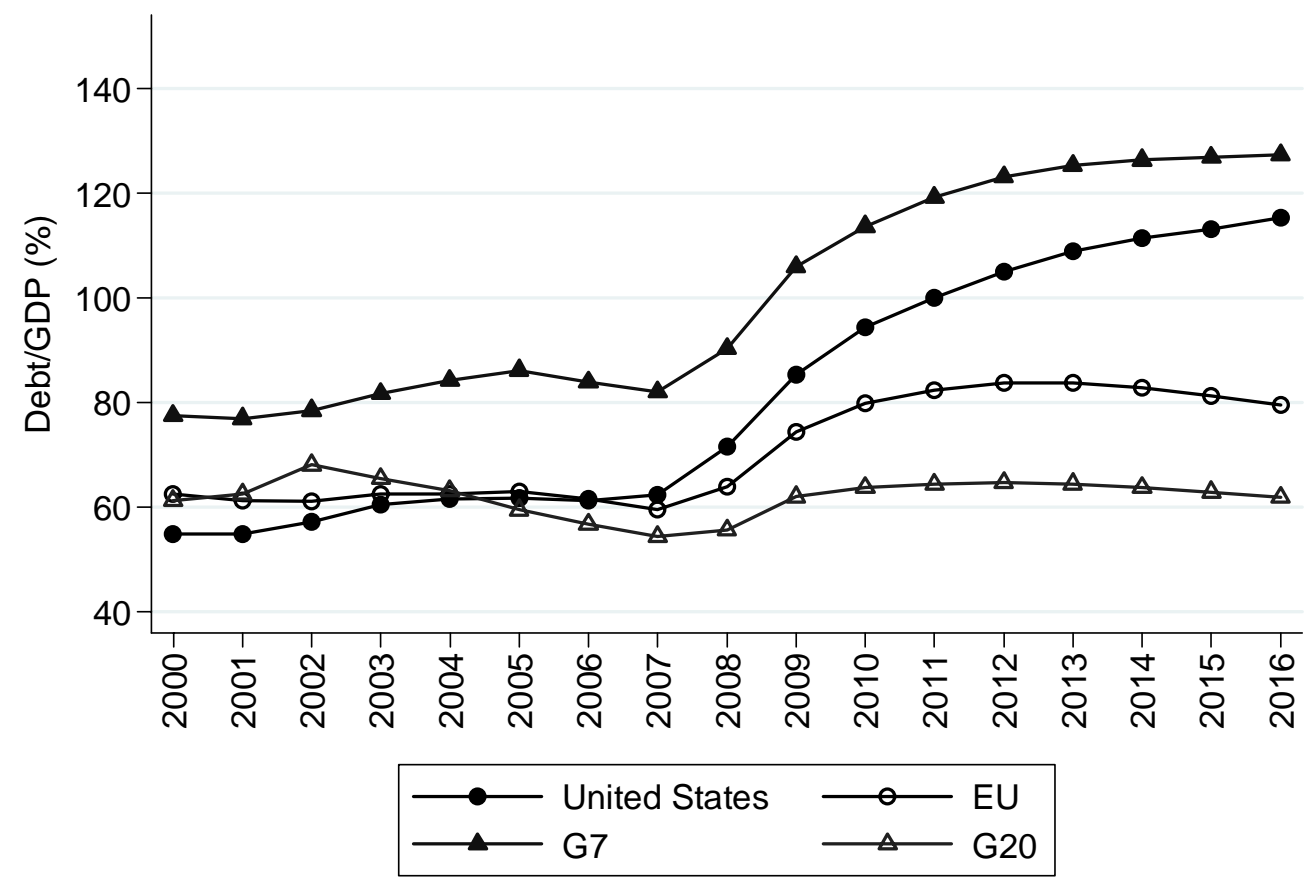

Source: IMF WEO September 2011

Figure 3a: Debt-to-GDP G20

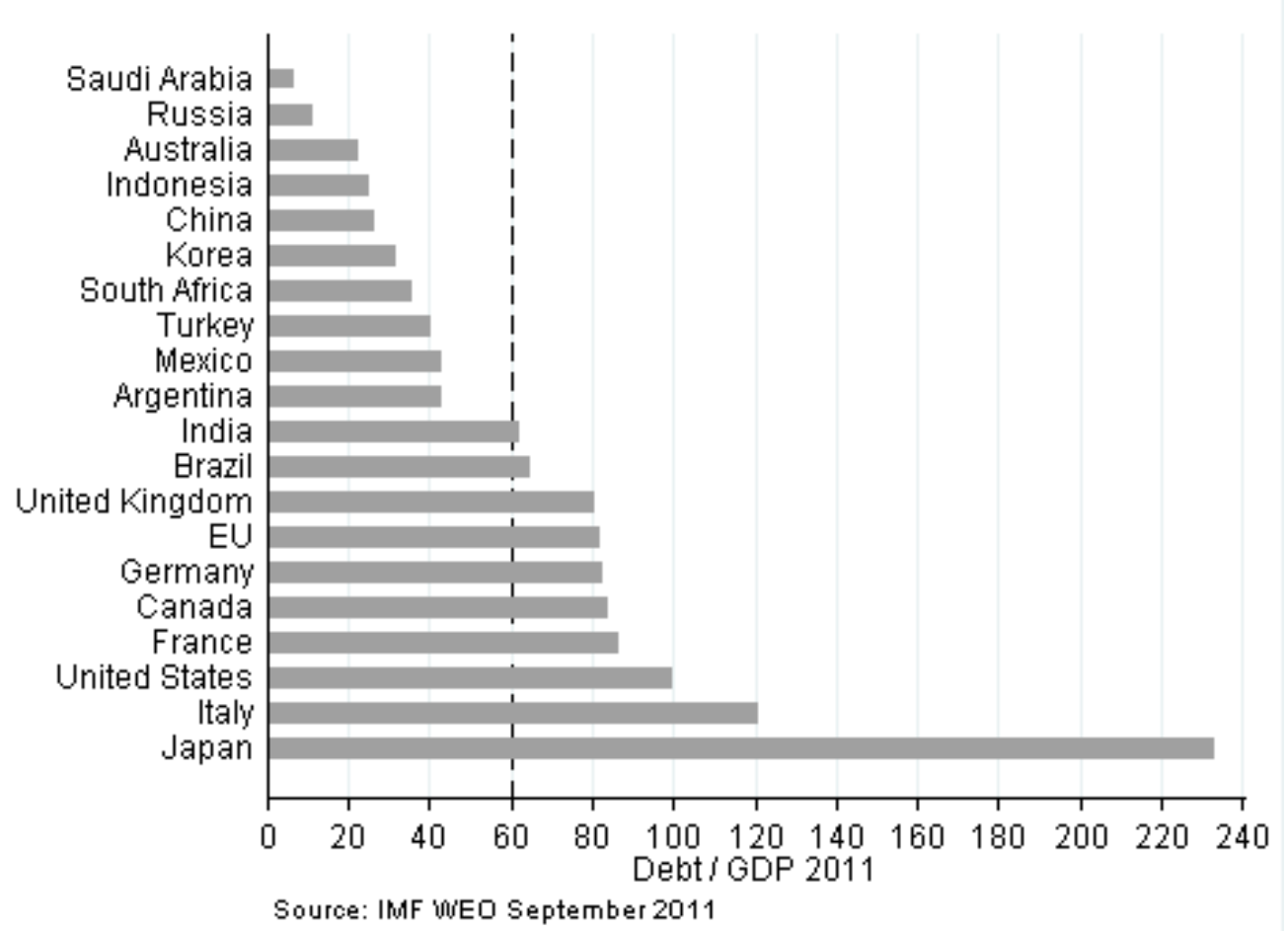


Figure 3b: General budget balance G20

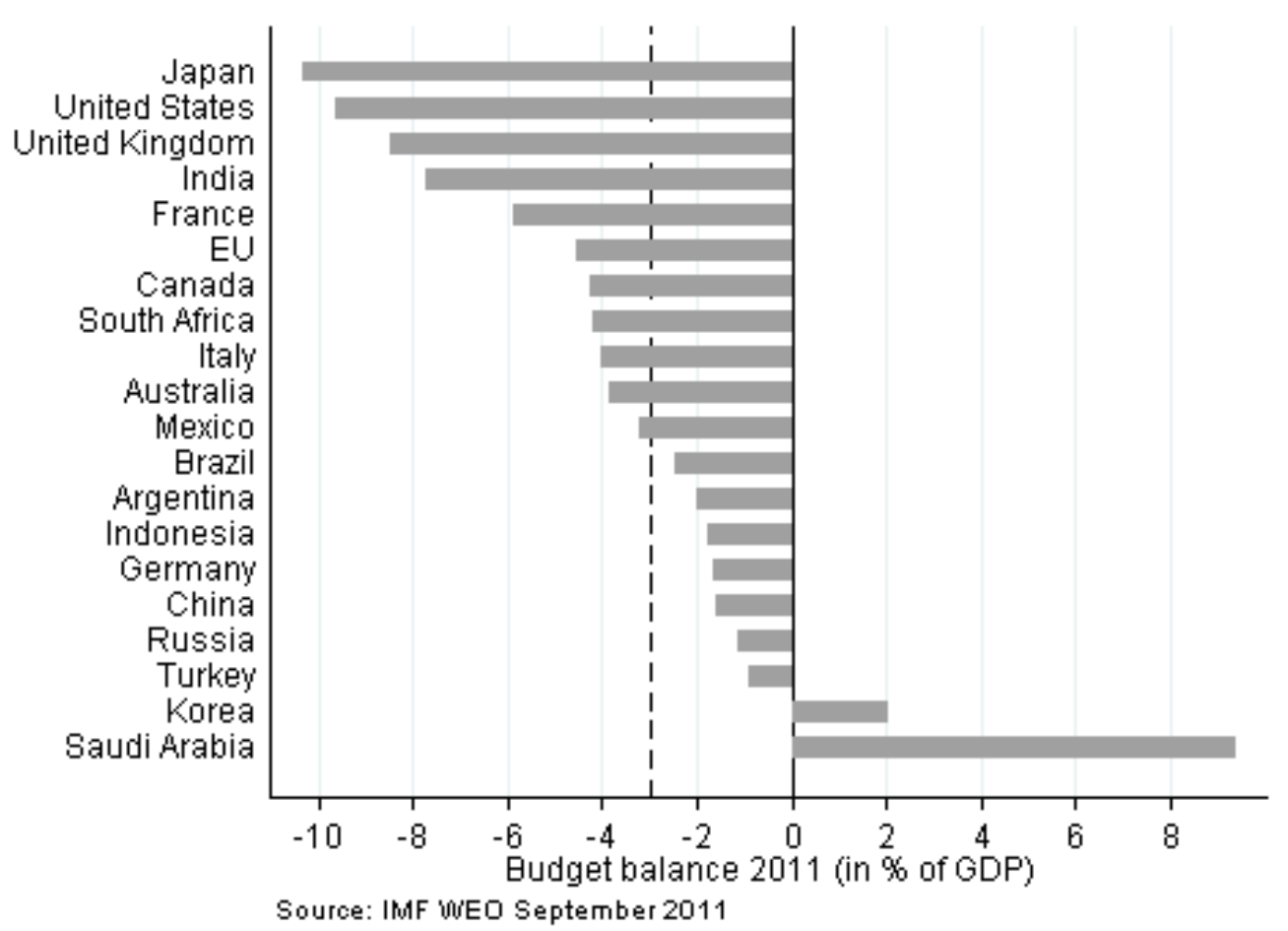

Figure 4: Debt-to-GDP ratios for 2007, 2011 and 2016

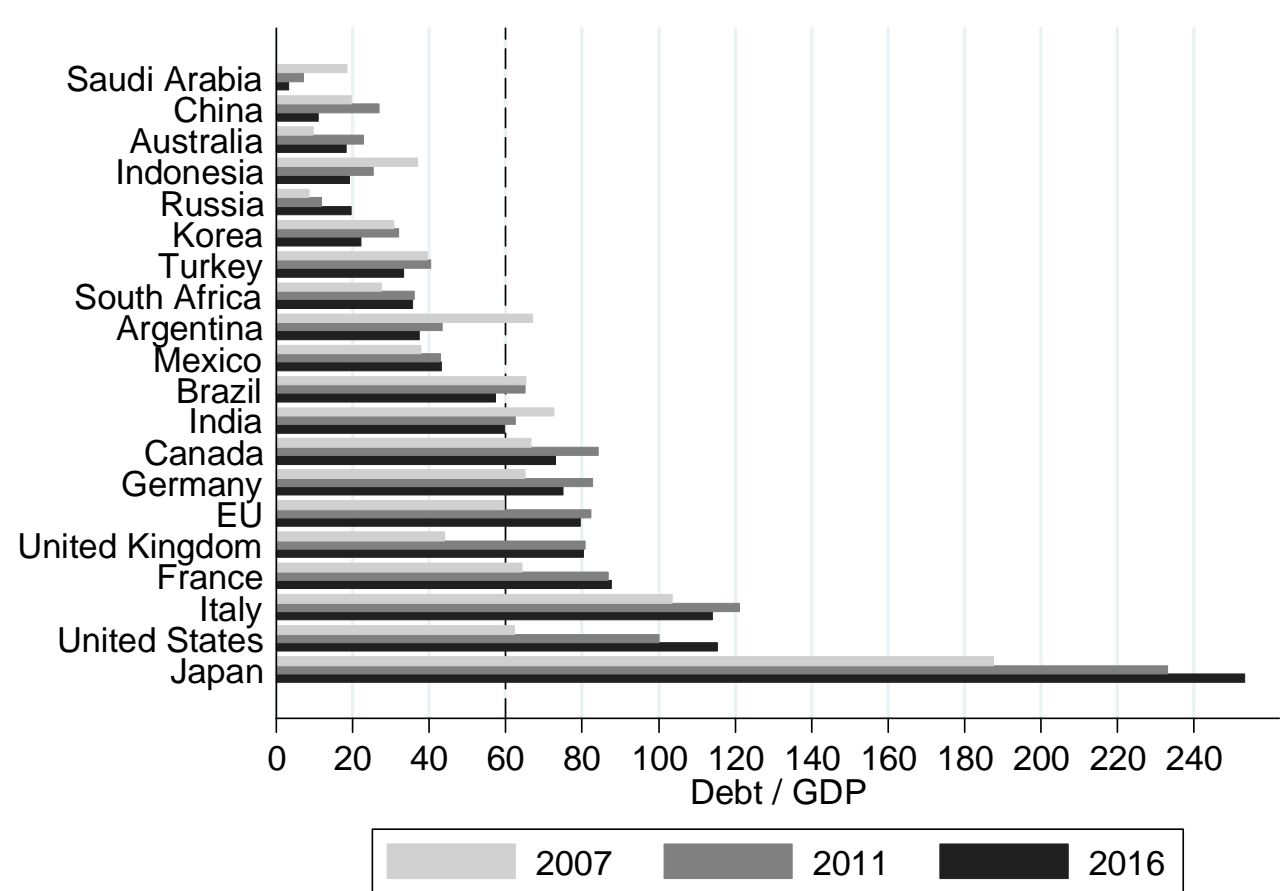

Source: IMF WEO September 2011 
Table 1: Actual and hypothetical debt / GDP

\begin{tabular}{lcccccc} 
& \multicolumn{3}{c}{ Debt / GDP } & \multicolumn{3}{c}{ Hypothetical Debt / GDP } \\
Country & $\underline{\mathbf{2 0 0 0}}$ & $\underline{\mathbf{2 0 0 7}}$ & $\underline{\mathbf{2 0 1 1}}$ & $\underline{\mathbf{2 0 0 7}}$ & $\underline{\mathbf{2 0 1 1 a}}$ & $\underline{\mathbf{2 0 1 1 b}}$ \\
\cline { 1 - 2 } Austria & 66 & 61 & 72 & 51 & 49 & 58 \\
Belgium & 108 & 84 & 95 & 81 & 75 & 86 \\
Brazil & 67 & 65 & 65 & 30 & 22 & 28 \\
Canada & 82 & 67 & 84 & 52 & 49 & 60 \\
France & 57 & 64 & 87 & 44 & 47 & 65 \\
Germany & 60 & 65 & 83 & 53 & 53 & 58 \\
Greece & 103 & 105 & 166 & 62 & 73 & 110 \\
India & 72 & 73 & 62 & 33 & 18 & 45 \\
Indonesia & 95 & 37 & 25 & 33 & 18 & 22 \\
Ireland & 37 & 25 & 109 & 15 & 27 & 83 \\
Italy & 109 & 104 & 121 & 87 & 90 & 100 \\
Japan & 142 & 188 & 233 & 139 & 161 & 187 \\
Portugal & 48 & 68 & 106 & 36 & 45 & 65 \\
Spain & 59 & 36 & 67 & 31 & 36 & 60 \\
United Kingdom & 41 & 44 & 81 & 28 & 31 & 58 \\
United States & 55 & 62 & 100 & 39 & 42 & 74
\end{tabular}

Source: IMF WEO September 2011 and own calculations

Note: Table shows the observed debt-to-GDP ratios (in \% of GDP) for 2000, 2007 and 2011 and the hypothetical government debt for 2007 and 2011 if countries had complied with the Maastricht rules from 2000 onwards: balanced budget if real GDP growth was positive, 3\%-deficit in case of negative real GDP growth, consideration of observed budget balances if they were above the requirements of the Maastricht Treaty. Scenario 2011b takes into account observed budget balances for the years 2008-2011. 